\title{
Post-Mining Reclamation as An Environmental Policy: A Gold Mining Case Study
}

\author{
Prawitra Thalib" ${ }^{1}$, Faizal Kurniawan ${ }^{2}$, Wahyu Aliansa ${ }^{3}$, Atiqoh Farhah Maulani ${ }^{4}$ \\ 1. Universitas Airlangga, Indonesia.E-mail: prawitra@fh.unair.ac.id \\ 2. Universitas Airlangga, Indonesia.E-mail: faizal@fh.unair.ac.id \\ 3. Universitas Airlangga, Indonesia. E-mail: wahyu.aliansa-2017@fh.unair.ac.id \\ 4. Universitas Airlangga, Indonesia. E-mail: atiqoh.farhah.maulani-2017@fh.unair.ac.id
}

\begin{tabular}{l}
\hline ARTICLE INFO \\
\hline Keywords: \\
Environment; \\
Mining; \\
Reclamation \\
\hline
\end{tabular}

\begin{abstract}
Gold mining in south-east Sulawesi Bombana is one of the potential natural resources in Indonesia. But nowadays the condition is due to lack of responsibility of the mining business to conduct post-mining reclamation in Bombana area, even though the mining activity has been carrying out mining business license. Post-mining activities are very important and must be done by the mining company, because it can minimize the destruction of natural environment in the mining site. The purpose of this research is to find out the mining conditions in the Bombana area as well as arrangements related to post-mine reclamation in the Bombana area. This study was written using the normative from data obtained by library research. Then related to the implementation of post-mining reclamation in Bombana is currently not carried out maximally, it is due to the uncertainty of regulations related to the post-mine reclamation obligations and the sanctioned rules that will be applied in the future still depend on local government regulations but the implementation is still not able to work effectively. So the steps that need to be taken in this case to avoid damage to the environment surrounding the mining site is necessary cooperation between the Government, the mining business actors and the community using soil conservation technology such as post-mining reclamation, which is regulated in a clear, transparent, accountable legislation.
\end{abstract}

\section{Introduction}

The ecological crisis is no longer a possibility of the future. Instead, it has become a contemporary reality that exceeds the limits of tolerance and environmental adaptability. ${ }^{1}$ Indonesia is a country that has a lot of natural wealth and crops, thank God for a blessing from Allah, as well as from mining products, but in the case of mine management, there are still many problems, especially problems regarding post-mining that cause mining excavation that has not been reclaimed. Natural resources are one of the most important

1 Suparto Wijoyo, Penyelesaian Sengketa Lingkungan (Settlement of Environmental Disputes) (Surabaya: Airlangga University Press, 1999), 1. 
capitals in national development and therefore must be utilized as much as possible for the interests of the Indonesian people and do not forget to pay attention to the sustainability living around. One of the main uses of natural resources is mining activities, but mining activities in addition to having a positive effect also have negative effects on the environment, especially the company, landscapes, changes in environmental aesthetics, flora and fauna habitat and damage to soil quality, It is important to understand that the environment and wealth contained therein are the grace of God ${ }^{2}$ to protect.

Mining is one industry that is very reliable by the Indonesian government because it can bring in foreign exchange reserves. Besides that, mining also helps to expand employment. Mining activities are one of the activities that include: explorations, exploitation, management of refining, removal of minerals and mining materials, therefore mining activities have the potential to damage the environment. Look closely at the elements included in the environment which includes all the creatures of God Almighty, animate and lifeless, large and small, moving and not moving, then it can be said that the environment is a resource. Why the environment is a resource because it is in accordance with the character and its very complex nature and fulfills all the elements contained in the contents of this nature. ${ }^{3}$

The preservation of the environment is one of the responsibilities of the whole community in the face of the earth. It is a major fact in mind that all mankind residing in the Earth and the environment has provided many benefits to life. Gold mining in the area of Bombana Regency is one example of natural resources originating from the environment and has provided many benefits to the human life. Nowadays, many companies are engaged in mining that compete for mining exploration to get double profit. Actually, mining exploration activity is not an illegal activity when it gets permission from local government that has authority to give mining business license for the company that will do mining exploration. ${ }^{4}$ However, nowadays, most mining companies that have conducted the exploration of gold mining in Bombana Regency do not perform post-mining land reclamation, resulting in damage to natural environment in the location of the former gold mining quarry. There was a gold mine in Bombana starting in mid-2008. And since then, miners from the island of Sulawesi and outside the island of Sulawesi, such as Java, Kalimantan, Manado, and Papua began to arrive to do gold mining. But the gold mining activity is a legal activity after launched SK Bupati Number 10/2008 about the obligation of miners to pay a card for a reload of Rp. 250,000 per person. One concrete evidence of the damage to the natural environment of the former gold mining site in Bombana is Langkowala River water in Bombana district is not flowing anymore because the river body has suffered heavy damage due to gold mining activities. The damage to the Langkowala River was conveyed by one of the members of the DPRD Bombana,

\footnotetext{
Prawitra Thalib, "Distinction of Characteristics Sharia and Fiqh on Islamic Law," Yuridika (2018): 447.

Supriadi, Environmental Law in Indonesia: An Introduction (Jakarta: Sinar Grafika, 2008), 2010.

Sambari Halim Radianto et al., "Analysis on the Implementation of Goods / Services Procurement Electronically at District Government Gresik," International Journal of Advanced Science and Technology 29, no. 6 (2020): 560.
} 
Rumiyanto. It can then be said that the ecological crisis is not a possibility that will happen in the future, but today has become a contemporary reality that exceeds the boundaries of tolerance and adaptation capabilities of the environment.

Business activities in the mining sector is one of the industries that is the mainstay of the Indonesian government, because with the existence of mining areas in Indonesia can invite foreign investors to build businesses in Indonesia and certainly can open a job for the people of Indonesia itself. But with the many benefits that resulted from mining is not balanced by the implementation of post-mining land reclamation, resulting in damage to the natural environment after the occurrence of mining activities, When it should human beings as creatures of God have an obligation to keep the Earth and its environment. ${ }^{5}$ The purpose of post-mining land reclamation is to return the forest benefit to return in accordance with its function. The need to understand ecological conditions is important in post-mine land reclamation. Because the post-mine land reclamation is expected to restore environmental conditions to look similar to the previous natural conditions. The key to the successful post-mining land reclamation relies heavily on the ecological conditions of the reclamation area. In the implementation of post-mining land reclamation required understanding of ecological sciences. Because with the understanding of ecological science, can easily know and determine the local types of pioneer in the area of the former mines. In addition, the ability of ecological knowledge can be used to observe the surrounding location when looking for local seeds and seedlings that are not available on site. The manifestation of post-mine land reclamation is that it can be used as a forest, farm, and tourist site. The choice of the reclamation scheme is certainly adjusted to the climate, the topography of land post mines, the existence of the land, the distance with urban centers and land status. There are several reason why forests were chosen for the reclamation scheme could be because the slopes formed after the regression process are still too steep for agricultural activities, the production of forest wood products is more profitable, forest plants may be planted only to fulfill aesthetic aspects, or the land status requires that ex-mining land be replanted with forestry plants ${ }^{6}$.

However, in the fact that the condition occurred in Bombana Regency, there are still many former gold mining mines that have not been reclaimed. It is also influenced by the local government, which requires businesses to reclaiming the post-mining land. Unlike the North Kolaka district which is a mining site but has a level of local government regulation that regulates the obligation to perform post-mining reclamation. The absence of postmining land reclamation rules in Bombanga district has made the mining business not feel a deep obligation to conduct reclamation activities. Unperformed post-mining land reclamation activities in Bombana Regency area, increasingly making people living in the area around Bombana Regency was disturbed because most of Bombana Regency community has a livelihood as a farmer. But because their land is reduced to the mining

5 Prawitra Thalib, Syariah: Konsep Dan Hermeneutika (Surabaya: Lutfansah Mediatama, 2013), 97.

${ }^{6}$ Hirfan, "Strategi Reklamasi Lahan Pasca Tambang," PENA TEKNIK: Jurnal IImiah IImu-IImu Teknik 1, no. 1 (2016): 101. 
site and after mining has not done reclamation, the average population residing in Bombana has poverty. According to one of the citizens residing in Bombana, the existence of a gold mine does not make the inhabitants of Bombana a forward and adequate population, but the citizens are still living on the poverty line.

With the lack of problems of post-mining land reclamation activities in Bombana district due to the lack of legislation at the level of local governments become the purpose of this writing to find out more a legal formulation about the conditions of gold mining in the Bombana district, and learn more about the role of the government of Bombana district to overcome the problem.

\section{Method}

This research uses of juridical normative and statute approach with a study that prioritizes a legal material in the form of legislation as a basic material in conducting research. And supported by data obtained by libraries (research library). The Statute approach is usually used to examine laws and regulations that are still lacking and even cultivate the practice of deviations both at the cultural level in the field. This approach is done by examining the issuing of laws and regulations relating to the literature (legal literature) being encountered. This legislative approach is for example by studying the consistency/suitability between basic and legal law, or between one law and another law. In the civil law system, it is clear that the Statute approach was first used. ${ }^{7}$ With a legal approach, in the face of legal facts, relevant legal forces are tracked, the provisions of the law in the breadth of articles containing the norm. The norm in logic is the proposition (normative).

\section{Legal Instruments and Environmental Policy}

The determination of legislation containing instrument of law is tested with the implementation of elements (uitvoering or implementation) and law enforcement (handhaving or enforcement) which is an eye part of the regulatory chain of environmental management. In formulating the environmental policy, the Government usually sets the objectives to be achieved. Environmental wisdom with follow-up guidance by means of how objectives are achieved in order to keep the community in contact. The law No. 23 of 1997 on Environmental Management (UUPLH) underpins the policy of environmental policy in Indonesia because the law, government regulation and implementation regulation are an instrument of wisdom (instruments van Belaid). ${ }^{8}$

Environmental Wisdom Instruments (Juridische Milieubeleidsinstruten) are determined by the Government through various means of preventive or at least recovery to the normal level of environmental quality. Indonesia has not known "general principles of

7 Philipus M. Hadjon and Tatiek Sri Djatmati, Legal Argumentation (Yogyakarta: Gadjah Mada University Press, 2017), 38.

8 Siti Sundari Rangkuti, The Dynamics of the Development of Constitutional Law and the Legal Environment (Surabaya, 2008), 91. 
Environmental policy" as well as the instrument of its implementation. In the UUPLH, several provisions are poured, but the formula is not careful. In developed countries including the Netherlands the pouring of these principles and instruments is one of the keys to the success of environmental management. The main instrument of environmental law that serves to prevent pollution is "environmental permits". Environmental licensing has a close relationship with environmental quality standards (baku mutu lingkungan /BML) and Environmental impact Analysis (analisis mengenai dampak lingkungan/AMDAL).

Gold mining in Wumbubangka Village is one of the gold mining areas in Bombana County. Mining activities are carried out by the company. Mining that causes the environment to become damaged when mining activity ends. Damage to land will be a very serious problem, because the society that originally used the land for farming or plantation activities will no longer be able to utilize the land as before. This will cause the death of the livelihood of local people and society will also feel the impact of soil damage in a long period of time, because to improve the condition of damaged soil takes a long time.

The reclamation and post mining rules have actually been set in the law No. 4 year 2009 concerning the Mineral and Coal Mining in Article 99 paragraph (1) says "Every IUP and IUPK holders shall submit a reclamation plan and a post-operative plan at the time of applying for IUP operation Production" paragraph (2) "The implementation of reclamation and post-mining activities are carried out in accordance with the provisions of the post mining land" and in article 100nya paragraph (1) "The IUP and IUPK holders shall provide the Reclamation Guarantee Fund and guarantee of the post" paragraph (2) "the minister, governor, or the Regent/mayor in accordance with its authority may assign a third party to perform reclamation and postulate with such collateral funds" subsection (3) "The provisions referred to in paragraph (2) shall be enforced if the IUP or IUPK holders do not carry out the reclamation and postulation in accordance with the approved plan", article 10nya "Further provisions on reclamation and post mining as well as the Guarantee Fund reclamation and collateral Fund of post mining stipulated by the government rules" is contained in PP No 78 yrs. 2010 about reclamation and post mining, and has been set also in the Regulation Bombana area No 14 year 2012.

\section{Principles of Postmining Reclamation and Productive Efforts in the Former Mining Mine Area}

The reclamation principles contained in PP No. 78 yrs. 2010 Pursuant to article 2 of government Regulation number 78-year 2010 about reclamation and post mining, IUP holder exploration and IUPK exploration must carry out reclamation and post-mining. Reclamation is done against disturbed land on exploration activities. Reclamation and postwar carried out against disrupted land on mining activities with systems and methods, open-mining and underground mining, reclamation plans and post mining must conform to the principles as stated in article 3 of government Regulation No. 78 year 2010 on reclamation and Postmining, Protection and environmental management of mining, 
occupational safety and health, and mineral and coal conservation. In addition, it must be in accordance with the mining systems and methods based on the feasibility study, the specific conditions of the mining business license area, and the provisions of legislative regulations. The fewest reclamation plans must contain:

a. Land use planning before and after mined.

b. Land Clearing plan.

c. The reclamation Program against the lava is interrupted which includes the former mines and land outside of the former mines that are temporary and/or permanent.

d. Success criteria include the success of land arrangement, revegetation, civil works, and final settlement; and

e. The reclamation fee plan consists of direct costs and indirect costs.

The reclamation principle and the post mining can be seen from some aspects of the first can be seen from the environmental aspects, occupational safety and health aspects and conservation aspects. These aspects are explained as follows:

a. Environmental aspects, in this aspect should observe and protect the quality of the surface water, groundwater, seawater, and soil and air, protecting the biodiversity, stability and security of the cover rock heap, the Taling pond, former mines and artificial structures (man-made structure), the use of former mines in accordance with the designation, and must also respect the values of social and local culture.

b. Occupational health and safety, in this aspect should pay attention to the safety protection of each worker and must safeguard every worker from the disease due to work.

c. Conservation, this aspect discusses the optimal development and the use of effective processing technology and the efficiency, management and/or utilization of a marginal backup of the mineral low quality and minerals of low content.

In addition to the above aspects, reclamation and postmining activity also have the aim to prevent natural disasters such as flood and landslide. Flooding occurs due to high enough rainfall, irrigation problems and the forest over function. Both irrigation and forest control problems are found in the mining area. The amount of mining and the activities of the notmanaged post-threshold has resulted in the production of water flow channels and rivers become shallow due to the disposal of waste that is not managed properly by the mining concerned. As happened in North Konawe on Saturday 1-June-2019, the number of mines in the area has resulted in flooding.

\section{Responsibility in Post-Mining Land Reclamation}

\subsection{Provisions for legal sue according land reclamation responsibility offences}

In a civil litigation process is manifestly less desirable or favored by the community in our country, when in a juridical, civil law enforcement room is one of the law enforcements instruments that govern that specifically related to the material matter formally must go 
through a civil justice process besides through an arbitrate. The thing that should be realized together that the civil dispute in the context of mining business in our country which is lively is happening today is a dispute between land owners and mining businesses. Recognizing this in the context of civil disputes, as outlined above, there are two tendencies. Firstly, on the one party, local people as landowners tend to be victims. Secondly, mining business actors tend to be more pleased to use civil lines because with various powers despite the court disputes, businesses can still perform its mining activities.

The accommodation of civil lawsuit on mining business that is detrimental to the public because of the complication or legal jurisdiction as stipulated in the provisions of Article 145 paragraph (1) of the Mineral and Coal Mining Law, which confirms that the community affected by the direct risk of mining business is entitled to a decent compensation due to errors in mining activities in accordance with the provisions of the legislation and submit a lawsuit against the court against the loss of mining exploitation that infringes the provisions. In this law there is no further provision or explanation of what is meant by mistake in mining activities.

These mistakes tend to lead to technical aspects, i.e. mistakes caused by human error, work implementation errors, or planning allergies, where the result of such mistakes caused harm to local communities, communities around the activities of mines and/or communities that are within range of the error itself.

\subsection{Provisions of administrative law enforcement violations of the post mining land reclamation responsibility breach}

In the management and the cloud of unrenewable Natural Resources is the authority and responsibility of the authorized officers in accordance with the laws and regulations. Mine management has an important role in meeting the needs of many people, and also has in providing national economic growth with continuous regional development. The implementation of administrative law enforcement is usually more preventive in order to encourage the perpetrators of a mining to comply and fulfill all provisions stated in the permits which in this case are IUP, IPR and IUPK. Therefore, in the context of law enforcement Administration is often also conducted through a short-term negotiation approach, persuasion, and supervision in order to make the regulations or conditions of permission be obeyed. That is, the first party and the main party in administrative law enforcement is the administration officials who issued the permit. In the event that this theory can be understood, because the administrative officials who issued the permit should be more aware of whether the activity has a permit or not, or whether the holder of the license issued violates the signs contained in the permit or instead otherwise.

In a management of the results of the mine has a lot of problems, especially in relation to the provision of a mining business license that can implicates the violation of the law. One of the customers is mal-administration that can result in a criminal offense. 
Maladministration has a legal concordance that must be held accountable for both personal responsibility and job responsibilities. Personal responsibility, relating to a functionary approach or behavioral approach. From the point of view of law Administration, personal responsibility is to be liable with the maladmisiration by the use of authority in public service. Job responsibilities regarding the legality of governmental acts. In the administration of the administrative issues concerning the Government's approach to government power. ${ }^{9}$

The implementation of administrative law in accordance with its function is preventive, the application of administration instruments is primarily intended for recovery of State or repair of damage or in other words is shown to its actions. Because of the essence of law enforcement through an administrative legal instrument it aims to act or neglect that is unlawful or does not comply with the requirements contained in the permit. Accordingly, the Act must be immediately terminated and immediately comply with the means of implementing the requirements. That is, the node administration's law enforcement is on its action object, and the authority to suppress the licensee adheres to the provisions or requirements that are licensed in the intended permission is an administrative compulsion.

In addition to coercion, administrative law recognizes the so-called administrative sanctions, namely the closure of the company, the Money force, and the withdrawal of permits. In connection with the application of administrative instruments in the context of implementation of mining business, the government has authority in the construction and supervision, whose authority is implemented by the Minister of Energy and Mineral resources. The victory of the government in terms of coaching is governed by article 139 of the Mineral and Coal Mining Law: 1. Provision of standards for mining business management; 2. Provision of guidance, supervision, and consultation; 3. Education and training; 4. Planning, research, development, monitoring, and evaluation of the implementation of mining business in the field of minerals and coal.

The administrative sanctions contained in the Law of the Republic of Indonesia No. 4 of 2009 on Mineral and coal Mining Article 151 paragraph (2) administrative sanctions as intended in paragraph (1) in the form of written warning, temporary suspension of part or all of the exploration activities or the production and/or the extraction of IUP, IPR, IUPK. And as the local government does not implement the provisions as intended in article 151 and HASL evaluation conducted by the Minister as intended in article 6 paragraph (1) Letter J, Minister may suspend and/or revoke IUP or IPR in accordance with the provisions of legislation.

9 Philipus.M. Hadjon et al., Hukum Administrasi Dan Good Governance (Jakarta: Universitas Trisakti, 2012), 94. 


\subsection{Criminal sanctions provisions of the land reclamation responsibility violations}

The criminal provisions in the Mineral and Coal Mining Law are the last instruments governed by the law, the provisions adapted to the development and the challenges of the mining world after the substitution of Law No. 11 of 2011 concerning the principal provisions of the mine, the consequence of the existence of criminal provisions in the Mineral and Coal Mining Law then the laws or provisions must be enforced. The criminal sanction provisions of the Mineral and Coal Mining Law are governed by Article 158 to section 165, which contains two types of criminal sanctions, namely sanction of imprisonment and penalty of confinement. Both types of sanctions were followed by fines, the provisions of the criminal sanctions referred to as Article 158 states that everyone who conducts mining business without IUP, IPR, and IUPK as referred to in article 37, article 40 paragraph (3), article 48, article 67 paragraph (1), article 74 paragraph (1) or paragraph (5) is sentenced to 10 (ten) years imprisonment and a fine of at most $\mathrm{Rp}$ $10,000,000,000.00$ (ten billion rupiah).

In article 159 the Mineral and Coal Mining Law states that holders of IUP, IPR or IUPK who intentionally convey the report as stated in article 43 paragraph (1), article 70 letter E, Article 81 paragraph (1), Article 105 paragraph (4), article 110 or article 111 paragraph (1) incorrectly or convey false information is sentenced with imprisonment of maximum 10 (ten) years and a fine of at most Rp. 10,000,000.00 (Ten billion rupiahs). The Mineral and Coal Mining Law of article 162, which reads: "Any person who is in the case of a mining business activity from an IUP or IUPK holder who has qualified as intended article 136 paragraph (2) is sentenced with a criminal confinement of at least 1 (one) year or a fine of at most Rp 100,000,000.00 (one hundred million rupiah)."

Furthermore, criminal sanctions for legal entities that commit violations other than the criminal that is dropped to the care is also applied to the statutory body itself. As stipulated in article 163, there are some criminal sanctions. First, the form of fine criminal with the circumcision plus $1 / 3$ (one-third) times from the maximum provisions of the penalty was dropped. Secondly, additional criminal is revocation of business license and/or revocation of legal entity status. While article 164 of the Mineral and Coal Mining Law, regulates provisions against perpetrators of criminal acts in violation of the provisions of Article 158 , article 159 , article 160 , article 160 , article 161 , and article 162 , may be subject to additional criminal deprivation of goods not used in committing a criminal offence, deprivation of profit obtained from criminal acts and/or obligation to pay expenses arising from criminal. Further, article 165 governs the provisions on criminal sanctions that are favorable by abusing authority by the State administration officials, which reads: "Any person who issued IUP, IPR, or IUPK in opposition to the Mineral and Coal Mining Law and misuse his authority is given a criminal sanction of two years imprisonment and a fine of at most Rp 200,000,000.00 (two hundred million rupiah)." Therefore, it is necessary to emphasize the mining business license (IUP) because in the IUP it is at least a lack of the 
reclamation and Reclamation Fund and the postwar guarantee as described in Article 39 paragraph (2) of Law No. 4 of 2009 on mineral and coal mining.

\section{Conclusions}

All ex-mining land must have benefits that must have economic, ecological, social and protection benefits, taking into account local cultural and social values, education, occupation and decent life belong to all human beings ${ }^{10}$ and local governments can realize it through the utilization of its natural wealth, but it should not cause environmental damage. The solution before the construction of reclamation and post-mining must be counseling from the local government to the community around the mine, the extension function so that people are no longer afraid, worried and anxious about the potential danger from reclamation and post-mining, besides local people also teach the crafts to sell, buy around these tourist attractions if the former mine is made as a tourist attraction by the government. The writer hopes that someday there will be land reclamation in general in all regions in Indonesia that have mining land that has not been reclaimed and postmining and especially in Southeast Sulawesi so that people get feedback from mining. It is not just a group or certain officials who benefit from the existence of the mine. The government must implement Legal Instruments and Environmental Policy Instruments related to mining issues, especially the Southeast Sulawesi government itself because it is clear that the law has regulated reclamation and post-mining. Responsibility, Administrative Sanctions and criminal provisions In Reclamation and Post-mining there is very clear Republic of Indonesia law number 4 of 2009 concerning mineral and coal mining, but regulations are only regulations, many problems of unfinished Mining Business Permits especially in Southeast Sulawesi, on February 11, 201 there were 22 companies which spread throughout Southeast Sulawesi but did not have IUPs but had already operated. The solution to mining operations must be stopped first because the mining business license does not yet exist which is very detrimental to the country, especially in the area, because in the IUP it must disclose post-mining reclamation and provide guarantees to the government. The security deposit is used to make tourist attractions in ex-mining quarries, build infrastructure, and the money can also be used for the capital of local residents to make handicrafts in the former mining site, in this way God willing, invite domestic and international tourism to come to the former mine, consequently raising the economy of local residents and slashing regional income as well.

\section{References}

Hadjon, Philipus.M., Paulus Effendie Loutulung, H.M. Laica Marzuki, Tatiek Sri Djamiati, and I Gusti Ngurah Wairocana. Hukum Administrasi Dan Good Governance. Jakarta: Universitas Trisakti, 2012.

Hadjon, Philipus M., and Tatiek Sri Djatmati. Legal Argumentation. Yogyakarta: Gadjah

10 Prawitra Thalib, Syariah Pengakuan Dan Perlindungan Hak Dan Kewajiban Manusia Dalam Perspektif Hukum Islam (Surabaya: Airlangga University Press, 2018), 178. 
Mada University Press, 2017.

Hirfan. "Strategi Reklamasi Lahan Pasca Tambang." PENA TEKNIK: Jurnal Ilmiah Ilmu-Ilmu Teknik 1, no. 1 (2016): 101-108.

Radianto, Sambari Halim, Suparto Wijoyo, Bagus Oktafian Abrianto, Prawitra Thalib, and Purnomo Edy. "Analysis on the Implementation of Goods / Services Procurement Electronically at District Government Gresik." International Journal of Advanced Science and Technology 29, no. 6 (2020): 559-568.

Rangkuti, Siti Sundari. The Dynamics of the Development of Constitutional Law and the Legal Environment. Surabaya, 2008.

Supriadi. Environmental Law in Indonesia: An Introduction. Jakarta: Sinar Grafika, 2008.

Thalib, Prawitra. "Distinction of Characteristics Sharia and Fiqh on Islamic Law." Yuridika (2018).

_-_. Syariah: Konsep Dan Hermeneutika. Surabaya: Lutfansah Mediatama, 2013.

- - - Syariah Pengakuan Dan Perlindungan Hak Dan Kewajiban Manusia Dalam Perspektif Hukum Islam. Surabaya: Airlangga University Press, 2018.

Wijoyo, Suparto. Penyelesaian Sengketa Lingkungan (Settlement of Environmental Disputes). Surabaya: Airlangga University Press, 1999. 